\title{
EVALUATION OF DATA OBTAINED FROM EXPERT OPINIONS IN MULTI-CRITERIA ANALYSES OF CONSTRUCTION INVESTMENT VARIANTS
}

\begin{abstract}
E. SZAFRANKO ${ }^{1}$
Planning a construction project, the investor frequently faces the choice of the option of the planned investment. Assessment of options is difficult due to the complex nature of construction projects. Various methods of multicriteria evaluation are successfully applied in the assessment and analysis of options. For those methods to work, a handful of information must be prepared beforehand. Among others, it is necessary to establish the assessment criteria and determine their weight for specific cases. This stage is implemented in cooperation with experts. The results of evaluations, obtained on the basis of the experts' opinions, must be processed and prepared. The paper will discuss one possible option for assessing the experts' opinion.
\end{abstract}

Keywords: multi-criteria evaluation, construction project variants, expert opinions

${ }^{1} \mathrm{PhD}$., Eng., University of Warmia and Mazury in Olsztyn, The Faculty of Geodesy, Geospatial and Civil Engineering, ul. Hewewliusza 4, 10-724 Olsztyn, Poland, e-mail: elasz@uwm.edu.pl 


\section{INTRODUCTION}

Evaluations conducted on the stage of planning the project require a number of decisions. Those decisions determine the final shape of the structure resulting from the investment and construction process. From selecting the appropriate site, through the shape, form and dimensions of the structure, to technological, material and structural solutions, the investor is faced with a number of decisions.[7] Assessment of construction projects requires developing and analysing several options of implementation of the project. The options are analysed in terms of technical and technological capabilities, economical aspects and environment protection conditions. Nature conservation regulations significantly impact the shape and cost of implementation of various projects, but most of all necessitate developing options for the design solutions due to the presence of environmentally sensitive habitats. It is important to include the principle of compensation measures, and monitor the hazards to and condition of the local environment. Also, potential conflicts with local communities are analysed; to prevent such conflicts, public consultations of the project are arranged. Another aspect to be taken into consideration is compliance with the local zoning plans [4]. Analysis of construction costs includes the cost of environmental protection, restrictions on the time frame for construction works, location, master planning conditions and construction of accompanying structures.[9]

\section{METHODS OF ANALYSIS APPLIED IN CONSTRUCTION PROJECT ASSESSMENT, AND EXPERTS' ASSESSMENTS}

The decision on implementing a project with a variety of different conditions requires an efficient method of assisting the decision-making, allowing the investor to include all significant aspects on the one hand, and on the other, to determine the option that will ensure the highest conformity with those aspects. Given the variety of available methods and techniques of option analysis, it is often difficult to decide which method to choose to achieve the desired effect. When deciding on the choice of the method, the key features to consider include clarity and quality of the obtained results, the applied mathematical apparatus, ease of application of the method and verification of results [8,9]. Supporting the multi-criteria decision-making requires participation of a host of experts, giving their opinions on a specific subject. The experts' opinions serve as basis for determining the significant criteria for further procedure. The opinions of the experts usually differ and arise from different 
perspective on the world and the processes occurring in it. The difference of opinion also arises from different functions performed by the experts in the investment process. Therefore, the assessments and the final outcome involve a certain degree of error that should be taken into account. Subjectivity is mainly found in methods based on assessment of qualitative factors. In the case of the so-called "measurable factors", assessment according to the given criterion becomes obvious. To obtain an objective assessment of qualitative factors, two approaches are applied. One involves a descriptive assessment of validity of the criterion, while the other requires using a numerical scale of measurement. Non-measurable factors often occur during the investment planning stage. These can be included in the decision-making process by various multi-criteria methods, such as: Multi-Criteria Evaluation (MCE), Analytic Hierarchy Process (AHP), ratio analysis [8, 9]. All of the methods listed above require gathering of large volumes of information to determine the value of criteria[7, 10, 11]. For this purpose, surveys and interviews with various groups of experts are conducted. The survey methods are discussed in detail in the literature on the subject.

To apply the MCE method, we need to gather information on the conformity with limitations of the first and second criterion group. In the case of limitations of the first criterion group, the analysis is conducted with the use of a zero to one scale. 1 - indicates conformity with a specific requirement, 0 - indicates non-conformity. An example of such limitations may be: a public road located not farther than $5 \mathrm{~km}$, the size of the plot on which we are planning construction over at least 1,500 $\mathrm{m} 2$, and e.g. the economical criterion - plot price not exceeding PLN 150,000. In the case of the second criterion group, an agreed-upon scale must be determined. The broader the scale, the more detailed the determination of conformity with the given requirements. For instance, a scale of 0 to 5 makes it possible to determine conformity with the criteria, if the criteria are few and the number of options to evaluate is small. Examples of determination of such scale include:

- an environmental criterion, determining whether the planned project requires tree clearing: 5 pts no clearing is required; 4 pts $-1-5$ trees must be cleared; 3 pts $-6-10$ trees must be cleared; 2 pts 11-20 trees must be cleared; 1 pt. $-21-30$ trees must be cleared; 0 pts - more than 30 trees must be cleared.

- criterion related to the need to construct environment protection facilities (e.g. in the case of roads, the number of necessary wildlife crossings must be provided). The need to construct such facilities indicates that the route will cut through environmentally sensitive areas and consequently will increase the costs: 5 pts - construction of wildlife crossings is not necessary; 4 pts $-1-3$ crossings must be constructed; 3 pts - 4-6 crossings must be constructed; 2 pts $-7-10$ crossings must be constructed; 1 pt. $-10-15$ crossings must be constructed; 0 pts - more than 15 crossings must be 
constructed. Similarly, when describing other phenomena, we establish the scale for other criteria. Applying a broader scale, e.g. 0 to 10 pts, increases the precision of evaluations. $[8,9]$

Conducting a survey to obtain data for ratio analysis of options requires determination of the scale of conformity with individual parameters of the prepared options, including negative values. The options require an approach that would include both the negative and the positive consequences of implementing the investment project. One example is the transport criterion which, on the one hand, reduces the travel time, and on the other hand, may increase the traffic volume by increasing the number of vehicles, or the traffic safety criterion, where travel becomes safer - and thus creates a positive effect - but connections with local roads increase the risk of traffic. The criteria should be described including the anticipated direct and indirect consequences of the planned project.

The starting point of evaluation conducted with the use of AHP is the matrix of comparison. Assessment of validity of criteria and importance of one criterion over another requires participation of experts. The experts' participation and the need to collect opinions of a number of people arise from different perspectives on the world and the processes occurring in it. Their opinions usually differ, and they found their positions based on different priorities, values, expertise, education and experience. In the AHP method, the person giving the opinion (with the use of the Fundamental Scale of pairwise comparisons of AHP) answers two types of questions on the importance of the compared elements: With respect to the given criterion, which of the two elements is more dominant/more important?; 2) Which of the two sub-criteria exercises larger influence on the third element, i.e. the main criterion? Aside from the pairwise comparison, the AHP decision-making scheme may utilize actual (real) numerical data and statistical data that reflect a problem or a part thereof (e.g. values determining costs, technical parameters of the project, etc.) $[8,9]$.

In all cases described herein, the result of the conducted surveys is a collection of information that must be processed for further computing. One of the steps involves the assessment of coherence of the obtained data. To determine, which opinion in the given case has higher value, weights increasing or reducing the importance of the opinion are sometimes introduced. This is the case e.g. when we wish to obtain information on the environment protection criteria. In such cases, opinions voiced by specialists in the field may have more weight. Other opinions are also considered, but due to the requirement of professional expertise, they are less important (have less weight). In many cases, the obtained values are averaged. The average value can also be included in the aggregation of the obtained assessment. 


\section{EVALUATION OF EXPERTS' OPINIONS}

The experts' opinions, due to different associations with the investment project, and different professional expertise and experience, may be more or less discrepant. Averaging the results does not always yield results that accurately reflect the situation and the analysed phenomenon. Therefore, in many cases it is necessary to summarise the obtained assessments by aggregation. This makes it possible to obtain more reliable evaluation outcomes.[1, 3, 6]

Aggregation of experts' assessment is complicated, therefore a number of approaches and methods have been developed over years of studies. One of the available methods is the probabilistic approach, which is probably the most comprehensive and most popular method. Under the probabilistic approach, a number of methods of aggregation of expert assessments have been developed, e.g. Bayesian inference, linear aggregation, weighted aggregation or assessments, behavioural aggregation, aggregation in logarithmic models, or Cook's distances.[2, 6, 9]

The experts' assessments may also take the form of scores. This approach is applied in the majority of multi-criteria analysis methods. Let us assume that, following the experts' assessments, we obtain the values for the evaluated criterion: $\mathrm{K} 1=2, \mathrm{~K} 2=3, \mathrm{~K} 3=5$. The criterion is evaluated on a scale from 1 to 6 . The weight of assessments is equal and amounts to $1 / 3$. The assessment is illustrated by Fig. 1.

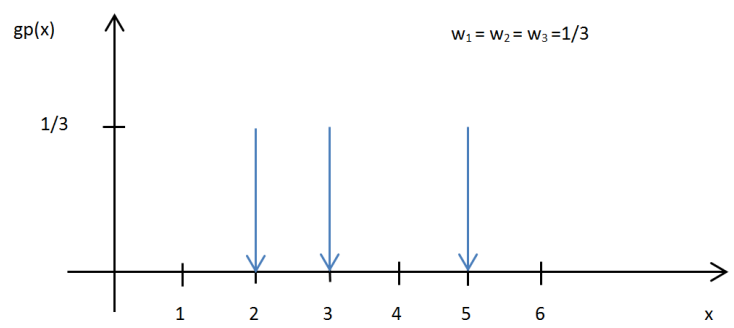

Fig.1. Visualisation of assessments of the evaluated criterion; source: the author based on [6]

Experts' scores are an example of a complete incoherence of opinion. Therefore, the method of linear aggregation cannot be applied in this case. In the interval of possible criterion values, there are (x) values of the evaluated criterion. The value (xn) is also the final, anticipated value of the criterion. Let us assume that $\mathrm{x} 4=4-$ this value does not conform to any of the experts' opinions. 


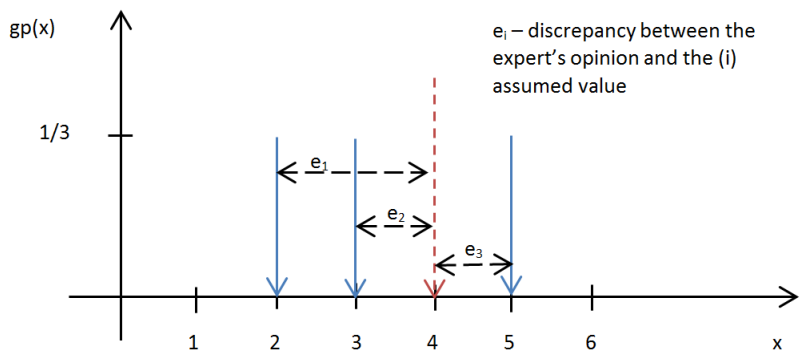

Fig. 2. Illustration of the assessment of discrepancy between the experts' opinions and the assumed value; source: the author based on $[1,6]$

As can be seen on Fig. 2, the assumed value does not conform to any of the experts' opinions. Each of the presented opinions involves an error, which can be read from the Figure and confidence coefficient, wi $=1 / 3$. The weighted sum of errors can be written down according to the following formula:

$$
S_{1}(x)=\sum_{i=1}^{3} w_{i}\left|e_{i}(x)\right|=\frac{1}{3} \cdot 2+\frac{1}{3} \cdot 1+\frac{1}{3} \bullet 1=\frac{1}{4}
$$

The weighted sum of errors of experts' opinions in equation 1 is one of the many available methods of assessment of discrepancy of those opinions.

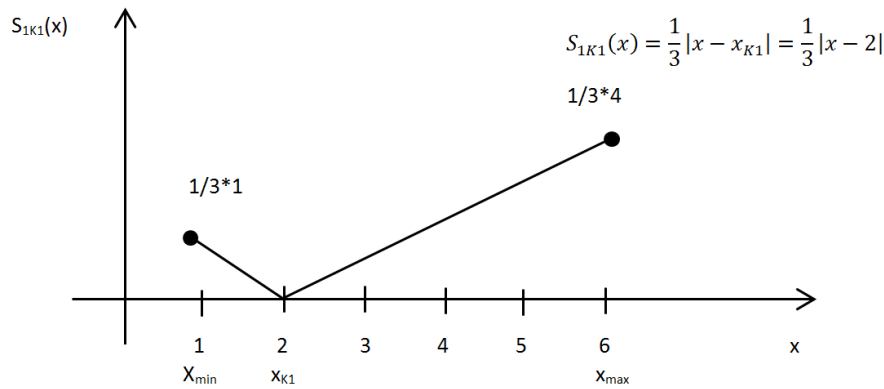

Fig. 3. Distribution of discrepancies $\mathrm{S} 1(\mathrm{x})$ of individual hypotheses $(\mathrm{X}=\mathrm{x})$ with the assessment $\mathrm{x}=2$; source: the author based on $[1,6]$

Evaluating the efficiency of assessments, we can e.g. compare individual assessments with the average value derived from all experts' opinions, or the weighted average (if we consider the expert's importance rating). Since, as evident from Fig. 2, it is not possible to determine such average value of assessments that would conform to all experts' opinions; we must find a value that will most 
accurately represent those assessments. For this purpose, distributions of discrepancies $\mathrm{S} 1(\mathrm{x})$ are developed for all possible values in the analysed interval of $1 \leq \mathrm{x} \leq 6$. The figure 3 presents an example of distribution for the value $\mathrm{xK} 1=2$.As can be seen, in the case of individual assessments, there is one hypothesis completely conformant with the expert's opinion. Other hypotheses are more or less discrepant.

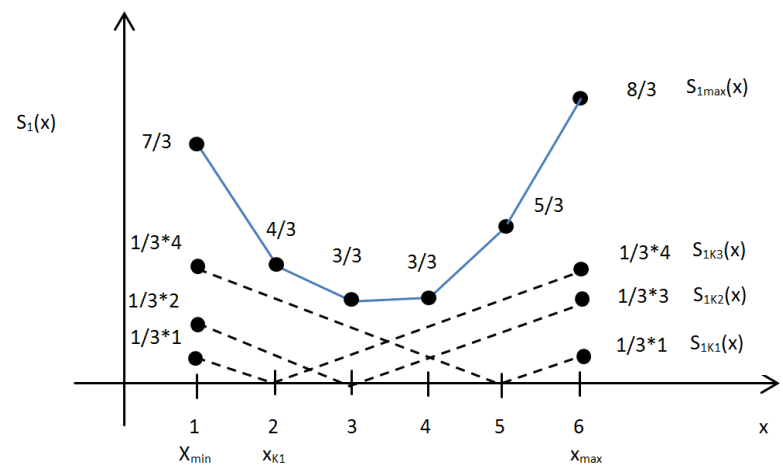

Fig. 4. Distribution of discrepancies of all evaluated opinions; source: the author based on $[1,6]$

This is the case when one opinion is evaluated. However, we are interested in the distribution of discrepancies of all evaluated opinions. It is illustrated by the scheme on Fig. 4.

\section{DISCUSSION OF THE RESULTS}

Surveys and interviews with experts generate dozens and sometimes hundreds of data. It is an extremely difficult and delicate task to prepare such vast amounts of information for further processing and the results of an analysis depend on whether the input data have been properly interpreted. As mentioned earlier, there are several different approaches. The easiest situation is when opinions of experts are quite similar. The extent to which opinions coincide can be assessed by analysing the cohesion of results. Methods for processing expert opinions enable their averaging; when the most frequently repeated statements are taken into consideration (should they prevail demonstrably). In many cases, an analysis is performed having discarded opinions of extreme quality (the ones which drastically differ from the others). In that case as well, it is not justifiable to apply highly sophisticated mathematical methods, which make an analysis unnecessarily complicated. 


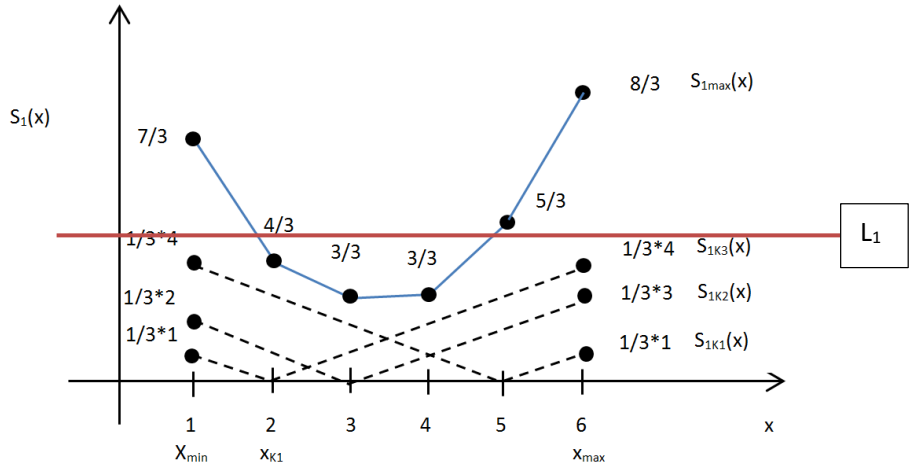

Fig. 5 The level of acceptance of the discrepancies analyzed opinions; source: the author

Line L1- the level of acceptance, drawn in fig. 5 shows that values 1, 5 and 6 should be discarded in the analysed case. This is a helpful clue in some situations because, should this be the case, the method can be replaced by an intuitive approach provided the researcher has some experience in performing similar analyses.

However, when data are highly divergent, the situation is more complicated. An opinion shared by the prevalent number of experts might not be conducive to conclusions; neither can an average or a median be drawn from incoherent data. If that is the case, one should reconsider whether the group of experts has been selected adequately or the questions expressed properly. If the problem arises due to the selection of respondents, then the situation can be improved by assigning weights to the replies. The study reported herein showed that the final effect would be identical to the one achieved with a much simpler method. The method of data aggregation described in literature [5] could be helpful in assessment of the acceptable degree of discrepancies between expert opinions. From the diagram in fig. 4, we can draw a horizontal line which will correspond to the threshold value that allows us to identify the values to be discarded from the subsequent analytical steps.

\section{SUMMARY}

Multi-criteria methods are useful whenever there are many factors decisive for the choice of a possible solution. In order to perform analyses and identify non-measurable factors, surveys are conducted that provide information about the importance of pre-defined criteria. Such surveys generate vast amounts of data, which must be prepared for further calculations. Making an assessment on the usefulness of information obtained from surveys and preparing the data for further processing calls 
for an adequate approach based on one's experience. There are many simple data processing methods, although more advanced techniques are also applicable. One possible solution for this problem is to employ data aggregation, described in literature and discussed in this article.

The method presented in this paper relies on the function of precise representation of expert opinions through a possible hypotheses $(\mathrm{X}=\mathrm{x})$ regarding a variable summited to an assessment. This method, which is relatively easy to apply, enables one to achieve a reliable assessment of data. The article deals with a version of the method based on the criterion of cumulative absolute error $\mathrm{S} 1(\mathrm{x})$ in a case of expert score opinions, which are the most frequent instant of the incoherence of data can be supplemented by data aggregation on the stage of preparation thereof for further stages.

\section{REFERENCES}

1. R.Clemen, R.Winkler, Combining probability distributions from experts in risk analysis, Risk Analysis, vol. 19, no. 2 .

2. S.Destercke, D. Dubois, E. Chojnacki, Possibilistic information fusion using maximal coherent subsets, IEEE Transactions on Fuzzy Systems 2009, vol. 17, no. 1.

3. D.Dubois, H. Prade, R.Yager, Merging fuzzy information, w: Fuzzy sets in approximate reasoning and information systems, Kluwer, Boston, MA 1999.

4. B.Hejmanowska, E.Hnat, Wielokryterialna analiza lokalizacji zabudowy na przykładzie gminy Podegrodzie. Archiwum Fotogrametrii, Kartografii i Teledetekcji, 2009.

5. A. O'Hagan, C.A. Buck et all., Uncertain judgements-eliciting experts' probabilities, John Wiley\&Sons, LTD, Chichester 2006.

6. A. Piegat, Funkcja r1(x) reprezentatywności hipotez i jej zastosowanie do agregacji ocen eksperckich, Zeszyty Naukowe Uniwersytetu Szczecińskiego, Studia Informatica nr 27/ 2011.

7. M.Połoński,2009 Kierowanie budowlanym procesem inwestycyjnym. SGGW, Warszawa 2009.

8. E.Szafranko, Ways to determine criteria in multi-criteria methods applied to assessment of variants of a planned building investment, Czasopismo Techniczne, (Technical Transactions) 2-/(6), 2014.

9. E.Szafranko, Metody analizy wariantów inwestycji drogowych. Drogownictwo, 1/2014.

10. S.Sandri, D.Dubois, H.Kalfsbeek, Elicitation assesment and pooling of expert judgments using possibility theory, "IEEE Transactions on Fuzzy Systems" vol. 3, no. 3. 1995.

11. K.Yoon, C.Hwang, Multiple Attribute Decision Making: An introduction, Sage Publications, London, 1995. 


\section{LIST OF FIGURES AND TABLES:}

Fig. 1. Visualisation of assessments of the evaluated criterion

Rys.1. Wizualizacja ocen badanego kryterium

Fig. 2. Illustration of the assessment of discrepancy between the experts' opinions and the assumed value.

Rys.2. Ilustracja oceny rozbieżności między opiniami ekspertów a wartością zakładaną

Fig. 3. Distribution of discrepancies $\mathrm{S} 1(\mathrm{x})$ of individual hypotheses $(\mathrm{X}=\mathrm{x})$ with the $\mathrm{x}=2$.

Rys.3 Rozkład niezgodności S1(x) poszczególnych hipotez $(\mathrm{X}=\mathrm{x}) \mathrm{z} \mathrm{x}=2$

Fig. 4. Distribution of discrepancies of all evaluated opinions

Rys.4. Rozkład niezgodności wszystkich opinii

Fig. 5. The level of acceptance of the discrepancies analyzed opinions

Rys. 5. Poziom akceptacji rozbieżności analizowanych opinii 


\section{OCENA KRYTERIÓW W WIELOKRYTERIALNYCH ANALIZACH WARIANTÓW INWESTYCJI BUDOWLANYCH}

Stowa kluczowe: analiza wielokryterialna, warianty inwestycji budowlanych, oceny ekspertów

\section{STRESZCZENIE:}

Wspomaganie decyzji wielokryterialnych wymaga udziału wielu ekspertów wyrażających swoje opinie na badany temat. W celu uzyskania obiektywnej oceny przyjmuje się dwa sposoby postępowania. Jeden to opisowa ocena ważności kryterium, drugi natomiast wymaga przyjęcia liczbowej skali pomiaru. Czynniki niemierzalne często pojawiają się przy planowaniu inwestycji. Możliwość ich uwzględnienia podczas podejmowania decyzji zapewniają nam różne metody wielokryterialne, np.: Analiza MCE, AHP, metody wskaźnikowe. Wszystkie wymienione metody wymagają zebrania dużej ilości informacji pozwalających ustalić wartości kryteriów. W tym celu przeprowadza się ankiety i wywiady wśród różnych grup ekspertów. Stosując metodę MCE musimy zebrać informacje o spełnieniu ograniczeń pierwszej i drugiej grupy. W przypadku ograniczeń pierwszej grupy do analizy służy skala zero- jedynkowa. 1 - oznacza spełnienie określonego wymogu, 0 - nie spełnienie. Przykładem takich ograniczeń może być: droga publiczna w odległości nie większej niż 5km; wielkość działki, na której planujemy budowę- co najmniej $1500 \mathrm{~m}^{2}$ i np. kryterium ekonomiczne cena działki nie większa niż 150 tys zł. W przypadku drugiej grupy kryteriów konieczne jest określenie skali umownej. Im szersza jest skala tym dokładniejsze określenie spełnienia danych warunków. I tak na przykład skala $0-5$ daje możliwość określenia spełnienia kryterium, gdy jest ich niezbyt dużo przy mniejszej ilości wariantów do przeanalizowania. Jak już wspomniano wcześniej, oceny ekspertów, bywają bardziej lub mniej rozbieżne. Nie zawsze uśrednienie wyników pozwoli osiągnąć efekt odzwierciedlający sytuację i badane zjawisko. Dlatego też w wielu przypadkach konieczne jest podsumowanie uzyskanych ocen poprzez ich agregację. Pozwala to osiągną bardziej miarodajne wyniki końcowe analiz. Oceny ekspertów są najczęściej ocenami punktowymi. Załóżmy, że w wyniku oceny ekspertów otrzymaliśmy wartości dla ocenianego kryterium: $\mathrm{K}_{1}=2, \mathrm{~K}_{2}=3, \mathrm{~K}_{3}=5$.

Kryterium jest oceniane w 6-cio punktowej skali. Punktowe oceny ekspertów są przykładem całkowitej niespójności opinii. W związku z tym metoda agregacji liniowej nie może być w tym przypadku zastosowana. W przedziale możliwych wartości kryterium istnieje $(x)$ wartości badanego kryterium. Wartość $(x)$ jest również ostateczną, oczekiwana wartością kryterium. Przyjmijmy, że x $=4$ - jest to wartość niezgadzająca się z żadną opinią ekspertów. Zgodnie z literaturą można opracować wykres niezgodności dla pojedynczej wartości. Jednak nas interesuje rozkład niezgodności wszystkich badanych opinii. Przedstawia go schemat na rysunku 4.

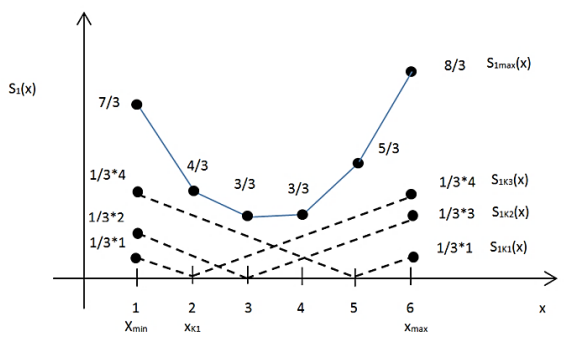

Rys.4. Rozkład niezgodności wszystkich opinii 


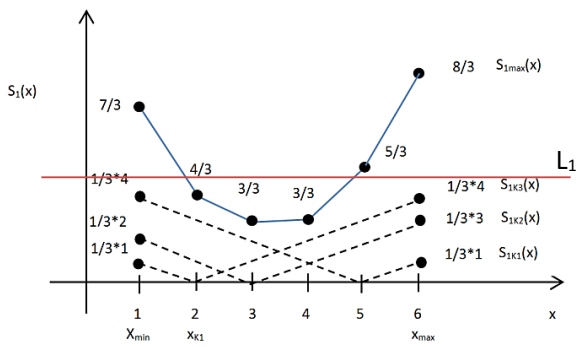

Rys.5. Poziom akceptacji rozbieżności analizowanych opinii

Linia $\mathrm{L}_{1}$ poprowadzona na rys. 5 pokazuje, że w rozpatrywanym przykładzie powinny być odrzucone wartości 1,5 i 6 . Jest to w pewnych sytuacjach pomocna informacja, jednak zakładając pewne doświadczenie w prowadzeniu takiego postępowania może metoda może być zastąpiona postępowaniem intuicyjnym.

W sytuacji, gdy mamy do czynienia z dużą niespójnością danych sytuacja jest trochę trudniejsza. Nie można się sugerować przeważającą opinią ekspertów, trudno też mówić o średniej czy medianie wynikającej z niespójnych danych. W takim przypadku należy się zastanowić nad prawidłowością doboru grupy ekspertów czy właściwym sformułowaniem pytań ankietowych. Jeżeli problem polega na doborze grupy ankietowanych to sytuację może poprawić wprowadzenie wag podnoszących znaczenie części odpowiedzi.

Metody analizy wielokryterialnej są przydatne wszędzie tam gdzie wiele czynników decyduje o wyborze rozwiązania dopuszczalnego realizacji inwestycji budowlanych. W celu przeprowadzenia analiz i określenia znaczenia czynników niemierzalnych przeprowadza się ankiety dostarczające informacji o znaczeniu wcześniej zdefiniowanych kryteriów. Takie badania są źródłem ogromnej ilości informacji, które wymagają przygotowania do dalszych obliczeń. Ocena przydatności uzyskanych danych i przygotowanie ich do dalszego postępowania wymaga odpowiedniego podejścia opartego na doświadczeniu. Jest wiele prostych metod opracowania danych, ale można również zastosować bardziej zaawansowane techniki. Jedną z możliwości jest opisana w literaturze i przybliżona w artykule metoda agregacji danych. 